\title{
The Effect of Personality, Organizational Climate and Job Satisfaction on Teachers Organizational Citizenship Behavior at Public Vocational High School in DKI Jakarta Province
}

\author{
Asari $^{1}$, Thamrin Abdullah ${ }^{2}$, Wibowo ${ }^{3}$ \\ ${ }^{1}$ Doctoral Program, Human Resource Management, Jakarta State University, Indonesia \\ ${ }^{2}$ Lecturer, Jakarta State University, Indonesia \\ ${ }^{3}$ Lecturer, Jakarta State University, Indonesia
}

\begin{abstract}
:
The purpose of this research to study the effect of personality, organizational climate and job satisfaction on Organizational Citizenship Behavior of teachers at public vocational high schools in Central Jakarta Administration city of Jakarta DKI Jakarta province. This study uses a quantitative approach with survey method. The population of this research is all civil servant teachers at 14 public vocational high schools in Central Jakarta Administration city area. The number of samples of the study were 212 teachers who were taken with the Slovin formula of a population of 451 teachers. The data collection research by questionnaires and then analyzed for statistically descriptive and inferential statistical path analysis. Based on the research hypothesis testing of the study found, 1)there is a direct positive effect of Personality on Organizational Citizenship Behavior, 2)there is a direct positive effect of Organizational Climate on Organizational Citizenship Behavior, 3)there is a direct positive effect of job satisfaction on Organizational Citizenship Behavior, 4)there is a direct positive effect of Personality on Job Satisfaction, and 5)there is a direct positive effect of Organizational Climate on Job Satisfaction.
\end{abstract}

Keywords: Organizational Citizenship Behavior, Personality, Organizational Climate and Job Satisfaction.

\section{Introduction}

One strategy faces global challenges to improve organizational effectiveness and sustainability with competitive advantage. Organizational resources that are dynamic to develop capacity as a source of competitive advantage are human resources (HR). This is in line with Raymond A. Noe's opinion that a way of relating to human resources that can be a source of competitive advantage is through the development of a set of human capital that gives a company a unique ability to adapt to an everchanging environment (Noe: 2010). The advantages of school organization one of them supported by the superiority of teachers in school. Teachers who have Organizational Citizenship Behavior (OCB) teachers are one of the competitiveness resources for school organizations. OCB attitudes of teachers in schools contribute positively to progress and increase school organizational productivity. Teachers with high OCBs are a capital of excellence and enhance the competitiveness of school organizations. The development of OCB starts from the business organization environment. Several studies have proven OCB as teacher empowerment and support school organizational effectiveness. First research conducted by Izhar Oplatka about OCB kindergarten teacher. Oplatka concluded that Kindergarten teachers who have OCB perform more professionally and interpersonally, (Oplatka, 2011). Both studies were conducted by Ronit Bogler who studied OCB teachers in schools in the role of decision-making participation. The research findings that teacher empowerment has an important role in mediating the relationship between teacher participation in decision-making and OCB. The involvement of teachers in the decision-making process will take on a new role and have a direct impact on the life of the school, which they end up doing extra effort in achieving school goals, (Bogler, 2005). The three studies conducted by Kasekende with the findings of his research that teacher empowerment has a significant relationship with OCB. Empowerment of teachers through planning activities, ongoing assessment and initiation of 
teacher competence, (Kasekende, 2016). All of these studies support the view that OCB-bound teachers contribute positively and improve school productivity. Teachers with OCB behaviors are a capital of excellence and enhance school competitiveness.

\section{Objectives}

The purpose of this research is to analyze the direct influence of personality, organizational climate, and job satisfaction towards Organizational Citizenship Behavior, direct influence of personality and organizational climate on job satisfaction.

\section{Literature review \\ Organizational Citizenship Behavior (OCB)}

Productive behavior is the behavior of workers who contribute positively to achieving the goals and goals of the organization. One form of productive behavior when workers do something unsolicited in formal job descriptions. The most important form of productive human behavior in organizations is Organizational Citizenship Behavior (OCB). According to OCB Organs defined: "individual behavior that is discretionary, not directly or explicitly recognized by the formal reward system, and in the aggregate promotes the efficient and effective functioning of the organization." (Organ, 2006). The definition of OCB contains two main behaviors: 1)free, voluntary, non-self-interest but for others (co-workers, groups, or organizations), and 2) not formally instructed, not recognized by a formal compensation or reward system. In the opinion of Borman and Motowidlo, the OCB is put forward by the contextual performance term (Organ, 1997): "behaviors that do not support the technical cores of the self-supporting the broader organizational, social, and psychological enviroment in which the technical core must function ". Colquit uses the term Citizenship Behavior as a form of behavior that contributes positively to an organization called the "Good Performer" category. Colquit gives the definition: Citizenship Behavior is defined as voluntary employee activities that in the workplace, (2009). Based on the benefits of employee Citizenship behavior, grouped into two namely: interpersonal citizenship behavior and organizational citizenship behavior. Citizenship behavior that benefits colleagues or colleagues is an interpersonal citizenship behavior category. Organ and Bateman provide a partial list of OCB behaviors namely, altruism, courtesy, sportmanship, civic virtue, and conscientiousness, (Sims Jr, 1992). Based on the study of various theories, it can be synthesized organizational citizenship behavior (OCB) is the behavior of workers who are volunteered and outside the main task that can contribute positively to the development and effectiveness of the organization, which is measured based on indicators: help colleagues, polite in work, tolerant in working, being a good organizational citizen, and obedient \& obedient to organizational rules.

\section{Personality}

Personality is one of human characteristics that is personal. The personality traits contribute to the tendency of human behavior. According to Gibson and Ivancevich the definition of personality is: An individual's personality is a relatively stable set of characteristics, tendencies, and temperaments that have been formed by inheritance and by social, cultural, and enviromental factors. The set of variables determines the commonalities and differences in the behavior of individuals, (Gibson, 2012). The definition explains that personality 1) the nature / character of a person is relatively long, 2) formed environment and genetic, 3) influence the behavior of individuals. Kinicki and Kreitner complete the definition of personality by detailing individual characteristics including physical and mental characteristics. The definition of personality according to Kinicki and Kreitner is more detailed as follows: Personality is defined as a combination of the stable physical and mental characteristics that give the individual his or her identity. These characteristics include genetic and enviromental influences (Kreitner, 2010). Personality definition according to Vecchio: personalilty can be defined as the relative enduring individual traits and dispositions that form a pattern distinguishing one person from the others, (Vecchio, 2006). The personality traits of a person though are individual and different to each person but can be described in dimension groups. One of the theories of personality dimension is the Big Five Model personality dimension consisting of: Conscientiousness, Extraversion, Agreeableness, Emotional stability, and Openness to Experience, (Gibson, 2012). Referring to the study of the theory of personality dimensions of the Big Five Model, it can be synthesized that personality is the nature and character of a relatively stable individual as a result of the interaction of heredity with the environment, which is manifested in the way of thinking, acting, and behave with indicators: sincerity in achievement of work performance, be proactive in the association in the work environment, maintain the trust given to 
him, be calm in the face of job constraints, and the willingness to learn.

\section{Organizational climate}

Organizational climate is defined in many different ways the point of view. Dessler defines by referring to a person's perception of the type of organization in which a person works. While Hellriegel and Slocum: a set of attributes which can be perceived about a particular organization and its subsystems, (Altman, 1985). The concept of organizational climate is widely used in research in the opinion of Tagiuri and Litwin namely: Organizational climate is a relatively enduring quality of the internal environment of an organization that is experienced by its members, (b) influences their behavior, and (c) can be described in terms of the values of a particular set of characteristic (attitude) of organization. Based on this concept, organizational climate becomes the distinguishing nature of one organization with another. According to Litwin organizational climate is: organizational climate is the quality or property of the organizational enviroment that (a) is perceived or experienced by organization members and (b) influences their behavior, (Kolb, 1984). Litwin's opinion is more pressing that the organization's climate shows the environmental quality of the organization. The quality condition of the organization's environment becomes part of the assets owned by the organization. Synthesis of organizational climate understanding is a relatively stable workplace organization environment condition perceived by its members as a result of perception and interaction with members that can influence attitudes or behavior toward their work with indicators, the autonomy of teachers in performing their professional duties, the belief in the leadership of the workplace organization, the support of the organization's social environment, appreciation of achievement and good performance, and emotional bonding with the organization.

\section{Job satisfaction}

Job satisfaction is one of the responses of one's attitude to the work it undergoes. Spector defines job satisfaction simply how a person feels about his job and different aspects of work, (Spector, 1997). Assessment of aspects of the human feelings of the work involves the individual psychological process. Locke provides a definition of work satisfaction by involving cognitive, affective, and evaluative responses or attitudes. The definition of work satisfaction by Locke, is a pleasant feeling or positive emotional state as a result of an assessment of work or work experience, (Luthans, 2011). Robbins argued that job satisfaction is a positive feeling about one's work which is the result of an evaluation of its characteristics, (2008). This statement explains that a person will obtain the level of job satisfaction that he or she hopes for if the organization in place of work provides a level of attention that is to be desired. Instead a person is not satisfied with his work by showing a negative attitude towards the job. The perspectives of the concept of job satisfaction from the various theories raised by the experts, according to Luthan there are three common dimensions that can be accepted related to the definition are: first, job satisfaction is the emotional response to the work situation; second, job satisfaction is often determined by how well the results found or exceeded expectations, third, job satisfaction represents some things related to attitude. (Luthans, 2011) While in the view of Steve M. Jex a positive attitude in job satisfaction consists of two components namely cognitive and behavioral (2002). The cognitive aspect in job satisfaction shows the worker's confidence about his work or condition. The beliefs about his job are interesting, boring, challenging many requirements. While the behavioral component represents a description of employee behavior or more often behavioral tendencies. Based on the study of various theories, it can be concluded that job satisfaction is a person's psychological response to his work as a result of assessment or work experience, with proud indicators of employment, suitability of work facilities, promotion opportunities, supervisory presence in the execution of work, and the existence of colleagues who support .

\section{Research Methodology}

This research is descriptive using survey method. Data analysis technique using path analysis. The population of this study is all civil servant teachers in state vocational high schools in the city administration area of Central Jakarta DKI Jakarta province. The number of schools that became the study there are 14 State Vocational Schools in the Central Jakarta Administration City area of DKI Jakarta province. The total target population as a whole is 451 teachers with civil servant status. Determination of the sample size of the entire target population using the Slovin formula, with a sample size of 212 teachers.

\section{Result}

Sub-structure 1

Table 1. Coefficients sub-structure 1 


\section{Coefficients $^{\mathrm{a}}$}

\begin{tabular}{|c|c|c|c|c|c|}
\hline \multirow[t]{2}{*}{ Model } & \multicolumn{2}{|c|}{$\begin{array}{l}\text { Unstandardized } \\
\text { Coefficients }\end{array}$} & \multirow{2}{*}{\begin{tabular}{|l} 
Standa \\
rdized \\
Coeffi \\
cients \\
Beta \\
\end{tabular}} & \multirow[b]{2}{*}{$T$} & \multirow[b]{2}{*}{ Sig. } \\
\hline & $\mathrm{B}$ & Std. Error & & & \\
\hline $\begin{array}{ll}1 & \text { (Const } \\
& \text { ant) }\end{array}$ & -28.535 & 6.368 & & -4.481 & .000 \\
\hline $\mathrm{X} 1$ & .359 & .058 & .303 & 6.186 & .000 \\
\hline $\mathrm{X} 2$ & .194 & .067 & .137 & 2.885 & .004 \\
\hline $\mathrm{X} 3$ & .643 & .063 & .523 & 10.163 & 3.000 \\
\hline
\end{tabular}

a. Dependent Variable: Organizational Citizenship Behavior $\left(\mathrm{X}_{4}\right)$

The structural equation formed in the first structural model is formed by the path coefficient from $X_{1}$ to $X_{4}, \quad X_{2}$ to $X_{4}$, and $X_{3}$ to $X_{4}$. The first substructural equation is: $\hat{X}_{4}=p_{1} X_{1}+p_{2} X_{2}+p_{3} X_{3}+\varepsilon 1$. Based on the calculation of path coefficient as in table 1 , the first equation model of sub-structure is $\hat{\mathrm{X}}_{4}=0,303 \mathrm{X}_{1}+0,137 \mathrm{X}_{2}+0,523 \mathrm{X}_{3}+0,587$.

Sub-structure 2

Table 2. Coefficients sub-strukture 2

Coefficients $^{\text {a }}$

\begin{tabular}{|c|c|c|c|c|}
\hline \multirow[t]{2}{*}{ Model } & \multicolumn{2}{|c|}{$\begin{array}{l}\text { Unstandardized } \\
\text { Coefficients }\end{array}$} & $\begin{array}{l}\text { Standardizec } \\
\text { Coefficients }\end{array}$ & \multirow[t]{2}{*}{ a) } \\
\hline & B & $\begin{array}{l}\text { Std. } \\
\text { Error }\end{array}$ & Beta & \\
\hline (Constant) & 27.895 & 6.687 & & 4.172 \\
\hline X1 & .389 & .058 & .402 & 6.757 \\
\hline $\mathrm{X} 2$ & .378 & .068 & .329 & 5.528 \\
\hline
\end{tabular}

a. Dependent Variable: Job Satisfaction

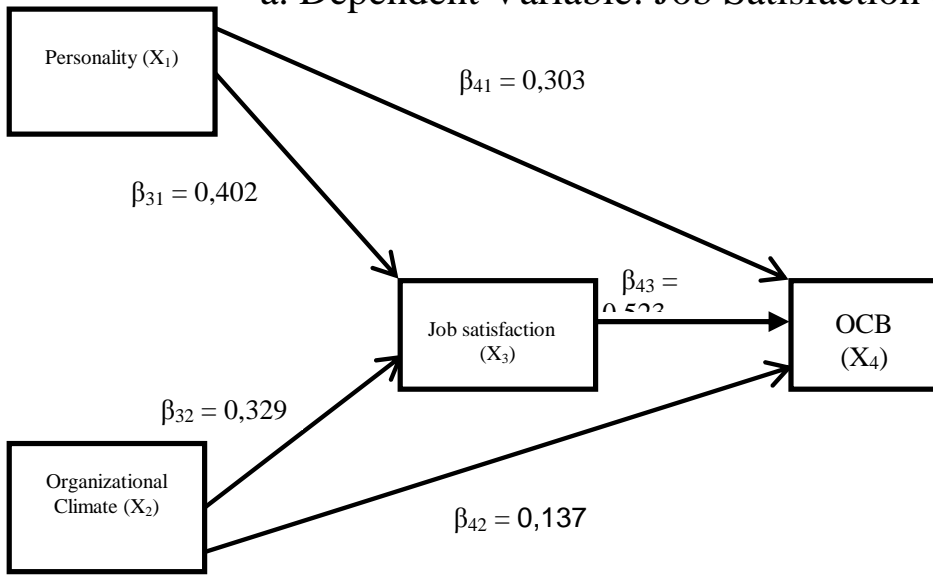

Figure 1. Model Research Structure Based on the Result of Path Analysis
The structural equations formed in the second substructural model are formed by path coefficients from $X_{1}$ to $X_{3}$, and $X_{2}$ to $X_{3}$. The equation of the structure of the second model: $\hat{X}_{3}=p_{1} X_{1}+p_{2} X_{2}+\varepsilon$. Based on the calculation of path coefficient as in table 2 then the form of equation model of the second structure, is: $\hat{\mathrm{X}}_{3}=0.402 \mathrm{X}_{1}+0.329 \mathrm{X}_{2}+$ 0.790 .

\section{Discussion \\ The effect of personality on Organizational Citizenship Behavior}

Personality has a direct positive effect on OCB. This means strengthening the personality traits will increase teacher OCB. The results of this study are in accordance with the opinion of the Organ states: heory also suggests that personality would predict OCB better than it would predict the more objectives indicators of productivity or technical excellence of job performance, (Organ, 2006: 89). The support of Steve Jex's theory explains the three factors behind the rise of OCB behavior. Steve Jex's opinion about personality factors: A third explanation for OCB is that it is due to disposition. According to this viewpoint, certain personality traits predispose indiv duals to engage in OCB, (Jex, 2002). Accodding to Rhenald Kasali the five personality traits of "the big five factors" are abbreviated with Stge QCEAN acronym, (Openness to experience, $.09^{\text {ns }}$ cientiousness, Extraversion, Agreeableness, Neorpticism) are each the shaping elements of change, (Kasali, 2007). The five personality traits 000 the nature of openness which includes openness (3)ife experiences, the heart and ear, the openness of others, the openness to agreement, and the openness to the pressures. To optimize the personality traits according Kasali use the term $\mathrm{Re}$ Code against Change DNA. Re Code in the process of change means we start by doing "treatment" on some people in a limited way by looking for anyone among them who is able to bring that change to more people.

\section{The effect of Organizational Climate on Organizational Citizenship Behavior}

The results prove the direct positive effect of organizational climate on OCB. This means to improve the OCB teachers by creating a conducive school organizational climate. The results of this study are consistent with findings by Jennifer ShuJen Lin and Shu-Cheng Lin relating to the organization's climate influence on OCB that when workers have a sense that they are valued and cared 
for by the organization, they will better show the services that lead OCB (Lin , 2011). The results of this study are of particular concern to stakeholders with vocational high schools. The role of principals as leaders and managers has a strategic role in creating an organizational climate in the school environment. The principal is the ultimate leader having the responsibility in creating a conducive school environment. The principal as a manager can manage the school by implementing school-based management to improve the quality of the organization's climate in schools. The principal's support determines the creation of productive working relationships between teachers and school administrators.

\section{The effect of Job Satisfaction on Organizational Citizenship Behavior}

The results of this study prove the direct positive effect of job satisfaction on OCB teachers. This means to increase OCB teachers by enlarging the level of teacher work satisfaction. The results of this study are in accordance with a review conducted by Priyanka, which concludes the influence of job satisfaction on OCB, that workers with high levels of job satisfaction are more likely to be tied to OCBs as indicated by the tendency to decrease other job searches (Priyanka, 2013). Explanation from the perspective of social psychology the effect of job satisfaction on OCB. Emotional responses result from workers' perceptions of their work. This means that job satisfaction shows a person's positive attitude toward his work. According to Steve Jex one of the main causes of OCB is positive affection (positive affect), especially in the form of job satisfaction (Jex, 2002). Theoretically this view comes from social psychology research showing that positive mood increases the frequency of help and other forms of spontaneous prosocial behavior. More positive moods and helpful behaviors (altruism) actually reinforce each other because helping others usually make people feel good.

\section{The effect of Personality on Job Satisfaction}

The results showed that personality has a direct positive effect on teacher job satisfaction. Job satisfaction will increase with the stronger personality traits of teachers. Personality traits as individual characteristics of teachers determine the attitude response to their work. This is in accordance with the opinion of Steve Jex, that one of the individual factors as the cause of job satisfaction is the personality. The explanation of the cause of job satisfaction with the personality approach that many workers have a tendency to be satisfied or dissatisfied with their work, regardless of the nature of the work or organization in which they work. The basic premise of the dispositional approach to job satisfaction (or dissatisfied) with their jobs, regadless of the nature of the job or organization in which they work, (Jex, 2002). The personality traits indicated by the seriousness in the achievement of work performance, the proactive attitude in the work environment, the willingness to agree on mutual agreement, the calm facing the obstacle, and the willingness to learn, as an indicator to form positive attitude toward the work. School principals and school management who have the task of maintaining and growing the teacher's personality to improve teacher work satisfaction in school.

\section{The effect of Organizational Climate on Job Satisfaction}

The result of research shows that there is positive influence of organizational climate to teacher work satisfaction. This means that the quality of the organization's climate in the vocational high school increases the teacher's job satisfaction. A conducive school organization climate will support the achievement of a better level of job satisfaction. School principals and school management are more instrumental in improving the quality of organizational climate aspects that exist in the school environment. Based on the study of organizational climate theory gives a picture of the relative stable condition of the workplace organization environment perceived by its members as a result of perceptions and interactions with members that can influence attitudes or behavior toward their work. Organizational climate formed by members' perceptions of the state of the working environment that includes the physical environment of the workplace, social environment, management system, and organizational culture. Based on the results of empirical testing of this study and the study of theory proves a quality organization climate shapes a person's positive attitude towards his work. Through a positive attitude towards the work formed by the climate of the organization will increase job satisfaction from workers.

\section{Conclusion}

Based on the analysis of the first research findings path there is a direct positive influence of personality, organizational climate, and job satisfaction on organizational citizenship behavior teachers. The research findings prove that strong 
personality traits, a conducive organizational climate, and great job satisfaction increase the Organizational Citizenship Behavior of teachers. Both results of this study prove the direct positive influence of personality and organizational climate on job satisfaction. Teacher job satisfaction is increasing with strong teacher personality traits and conducive school organizational climate.

\section{Recommendation}

The principal has an important role in strengthening the personality traits through the role of model, change agent, and change leader. The principal as a leader is responsible for creating a conducive school organizational climate. That is by applying democratic leadership, involving teachers in school policy-making processes, transparency and information disclosure in school management, fostering positive values within the school organization environment. Principals as managers can increase teacher work satisfaction in schools improved through improved school management. That is school management by applying a reward system based on teacher performance, empowering teacher profession organization and teacher work group at school level, facilitating and supporting teacher profession development, and providing promotion opportunity with justice principle.

\section{Refferences}

[1] Altman, Steven, Enzo Valenzi, and Richard M. Hodgetts. Organizational Behavior: Theory and Practice. Orlanda Florida: Academic Press, Inc. 1985.

[2] Al-Shammari, Minwir M., "Organizational climate" Leadership \& Organization Development Journal, vol 13, edisi 10 tahun 1992.

[3] Bogler, Ronit and Anit Somech. "Organizational citizenship behavior in school: How does it relate to participation in decision making?" Journal of Educational Administration;Armidale Vol. 43Iss. 4/5, (2005): 420-438. Emerald Group Publishing, Limited 2005.

[4] Colquit, Jason A., Jeffery A. Lepine, Michael J. Wesson. Organizational Behavior Improving Performance and Commitment in the Workplace. New York: McGraw Hill Irwin, 2009.

[5] Gibson, James L., John M. Ivancevich, Donelly, and Konopaske.2012. Organizational Behavior, Structure,
Processes. Fourteenth Edition. New York: McGraw Hill.

[6] Ivancevich, John M., Robert Konopaske, dan Michael T. Matteson. Perilaku dan Manajemen Organisasi. Edisi Ke tujuh, Jilid 1. Jakarta: Erlangga, 2011.

[7] Jex, Steve M. Organizational Psychology A Scientist-Practitioner Approach. New York: John Wiley \& Son Inc, 2002.

[8] Kasekende, Francis. "Linking teacher competences to organizational citizenship behaviour" The International Journal of Educational Management; Bradford Vol. 30, Iss. 2, (2016): 252-270. Emerald Group Publishing Limited 2016.

[9] Kasali, Rhenald. Re-Code Your Change DNA Membebaskan Belenggu-belenggu untuk Meraih Keberanian dan Keberhasilan dalam Perubahan. Jakarta: PT. Gramedia Pustaka Utama, 2007.

[10] Kreitner, Robert and Angelo Kinicki. Organizational Behavior, Seventh Edition, New York: McGraw Hill, 2010.

[11] Kolb, David A., Irwin M. Rubin, and James M. Mclntyre (editor). Organizational Psychology Readings on Human Behavior in Organizations, fourt edition, New Jersey: Prentice Hall, Inc. 1984.

[12] Lin, Jennifer Shu-Jen and Shu-Cheng Lin, "Moderating effect of organizational climate on the relationship of organizational support and service-oriented organizational citizenship behaviors" African Journal of Business Management Vol. 5 (2), pp. 582595, 18 January, 2011.

[13] Luthans, Fred. Organizational Behavior An Evidence Based Approach. New York: McGraw Hill Irwin, 2011.

[14] Noe, Raymond A., Jon R. Hollenbeck, Baary Gerhat, dan Patrick M. Wright. Manajemen Sumber Daya Manusia: Mencapai Keunggulan Bersaing. Jakarta: Salemba empat, 2010.

[15] Oplatka, Izhar and Masada Stundi. "The components and determinants of preschool teacher organisational citizenship behaviour " The International Journal of Educational Management ; Bradford Vol. 25, Iss. 3, (2011):223-236. Emerald Group Publishing Limited 2011.

[16] Organ, Dennis W., Philip M. Podsakoff \& Scott B. MacKenzie. Organizational Citizenship Behavior: Its Nature antecedents 
and consequences. Californa: SAGE Publications, Inc., 2006.

[17] Organ, Dennis W. "Organizational Citizenship Behavior: It's Construct CleanUp Time". Human Performance, 10(2), 8597 Lawrence Erlbaum Associates, Inc.

[18] http://edi-info.ir/files/Organizationalcitizenship-behaiviour.-its-construct-cleanup-time.pdf

[19] Sims Jr., Henry P. \& Peter Lorenzi. The New Paradigm Leadership Social Learning and Cognition in Organization. California: Sage Publication, 1992.

[20] Steers, Richard M. Introduction to Organizational Behavior. Boston USA: Scott, Foresman and Company, 1988.

[21] Vecchio, Robert P. Organizational Behavior. USA: Thomson. 2006.

[22] Yadav, Priyanka and B. K. Punia, "Organisational Citizenship Behavior : A Review of Antecedent, Correlates, Outcomes and Future Research Directions "IJHPD Vol. 2 No. 2 July - Dec. 2013. 